\title{
Efficacy of Organic Manures and Biofertilizers on Soil Microbial Count and Yield of Black Nightshade (Solanum nigrum L.)
}

\author{
M. Ammaan ${ }^{1 *}$ and S. Subramanian ${ }^{2}$ \\ Department of Spices and Plantation Crops, Horticultural College and \\ Research Institute, TNAU, Coimbatore, India \\ *Corresponding author
}

\begin{abstract}
A B S T R A C T
Keywords

Black night shade (Solanum nigrum L.), organic manures, biofertilizers.

Article Info

Accepted:

19 June 2017

Available Online:

10 July 2017

Black night shade (Solanum nigrum L.) belongs to the family 'Solanaceae' is an important medicinal plant which has tremendous medicinal value. The plant contains alkaloids like solamargine, solanigrine and solasonine. The herb is credited with emollient, antiseptic, leucoderma, piles, ulcer, asthma and eye troubles. Makoi leaves are also known to suppress carcinogenesis and have high market value. Farmers growing this crop will also get high net return. A field experiment was carried out at HC\&RI, TNAU, Coimbatore during 2012-13 to study the effect of organic manures and biofertilizers on Black night shade on quality parameters. Soil application of different graded levels of organic manures and biofertilizers was applied i.e., T1- FYM @ 8t/ha + foliar spray of 1\% PPFM, T2T1+Azophos@2kg/ha, T3- T1+Azophosmet @ 2kg/ha, T4- Vermicompost @ 6t/ha + foliar spray of 1\% PPFM, T5- T4+Azophos@2kg/ha, T6- T4+Azophosmet@ 2kg/ha, T7Poultry manure@ 4t/ha + foliar spray of 1\% PPFM, T8- T7+Azophos @ 2kg/ha and T9T7+Azophosmet@2kg/ha was carried with three replications. Foliar spraying of 1\% PPFM was taken up at 45th day after sowing and later at 15 days after first and second harvest i.e., 75 and 105 DAS. The highest Solasodine content $(0.4 \%)$ was observed in the treatment $\mathrm{T}_{6}$. The increase may be due to synergistic and compatible effect of organic manures and biofertilizers application.
\end{abstract}

\section{Introduction}

Solanum nigrum L. (commonly known as 'Black night shade" in English and 'Makoi' in Hindi) belongs to the family 'Solanaceae' is an important medicinal plant which has tremendous medicinal value. The economic parts of the plant are leaves, berries and even the whole herb. The plant contains alkaloids like solamargine, solanigrine and solasonine. The herb has antiseptic, anti-dysenteric properties and used against abdominal upsets. The plant is also credited with emollient, diuretic, anti-spasmodic and laxative properties. It is used in heart diseases, fever, pain, leucoderma, piles, ulcer, vomitting, asthma and eye troubles. The berries and leaves are mainly used for medicinal purposes, besides the other parts of the whole plant. The leaves are used as poultice for rheumatic and gouty joints, dropsy, nausea and nervous disorders. The decoction of the berries and flowers are useful in cough, erysipelas (specific, acute, cutaneous inflammatory disease caused by a haemolytic streptococcus and are characterized by redhot). Makoi leaves are also known to suppress carcinogenesis. These are remedy 
for pulmonary tuberclosis and Bronchitis, diuretic. The juice of the berries used as an antidiarrhoea, opthalmopathy and hydrophobia. It is also used in anasarca and heart disease. Berries are used to possess tonic, diuretic and cathartic properties. Seeds are useful in giddiness and dipsia. They are also useful in inflammations and skin diseases. The roots are useful in otopathy, ophthalmopathy, rhinopathy and hepatitis. The whole plant used as antiseptic, antiinflammatory, expectorant, cardiotonic, digestive, diuretic, laxative, diaphoretic, sedative, swelling, cough, asthma The plant is also effective in curing cardiopathy, leprosy, haemorrhoids, nephropathy, ophthalmopathy, dropsy and general debility.

Decoction of the plant depresses the Central Nervous System and reflexes of the spinal cord (Saleem et al., 2010). Cultural practices such as cultivation, intercropping, rotation, drainage use of pesticides, and fertilizers have vital implications for the microorganisms, number of fungi, bacteria, actinomycetes, yeast, and protozoa present in the soil (Hengeveld, 1996). Soil microbiology traditionally deals with the study of microorganisms and their processes in soil. The interaction among organisms and their environments involves soil ecology (Paul, 2007). Soil is a heterogeneous medium of solid, liquid and gaseous phases varying in its properties both across the landscape and in depth (Luo and Zhou, 2006).

Soil microorganisms significantly contribute to the maintenance of the matter and energy turnover in terrestrial environment. Soil represents one of the most significant places for biogeochemical processes, in which mineralization has a very important role. Soil respiration is an ecosystem process that releases carbon dioxide $(\mathrm{CO} 2)$ from soil root respiration, microbial decomposition of litter and soil organic matter and fauna respiration.
Since the global carbon regulates climate change, soil respiration also becomes relevant to climate change, carbon trading and environmental policy. Soil respiration plays a crucial role in regulating atmospheric $\mathrm{CO} 2$ concentration and in climate regulation. The carbon cycle on the global scale involves exchanges of $\mathrm{CO}_{2}$ among the land biosphere, atmosphere, oceans and the earth crust (Luo and Zhou, 2006). PPFMs influence seed germination and seedling growth by producing the plant growth regulator zeatin and related cytokinins, due to the production of plant hormone and vitamins by pink pigmented facultative methylotrophic bacteria colonizing on the phyllosphere regions of maize (Sundaram et al., 2002). Mineralization tests are very often used for testing the soil microbial activity. $\mathrm{CO}_{2}$ production enables to evaluate both mineralization activity of native soil organic matter and potential activity of soil after addition of nutrients.

As there is a growing demand for organically grown herbal products in national and international markets, an attempt has been made to assess the effect of different organic manures and biofertilizers on the soil microbial count and yield of Solanum nigrum L. with the following objectives.

To study the effect of organic manures and biofertilizers on soil microbial count and to study the effect of organic manures and biofertilizers on yield of Solanum nigrum L.

\section{Materials and Methods}

A field experiment was carried out at the Department of Medicinal and Aromatic Crops, Horticultural College and Research Institute, Tamil Nadu Agricultural University, Coimbatore during 2012-13 in randomized block design which was replicated thrice to study the effect of organic manures and biofertilizers on Black night shade soil 
microbial count and yield characteristics in sandy clay loam soils in spacing of $60 \times 30 \mathrm{~cm}$.

Soil application of different graded levels of organic manures and biofertilizers was applied i.e., T1- FYM @ 8t/ha + foliar spray of 1\% PPFM, T2- FYM @ 8t/ha + Azophos @ 2kg/ha + foliar spray of 1\% PPFM, T3FYM @8t/ha + Azophosmet @ 2kg/ha + foliar spray of 1\% PPFM, T4- Vermicompost @ 6t/ha + foliar spray of 1\% PPFM, T5Vermicompost@6t/ha +Azophos @ 2kg/ha + foliar spray of 1\% PPFM, T6Vermicompost@6t/ha + Azophosmet @ $2 \mathrm{~kg} / \mathrm{ha}+$ foliar spray of 1\% PPFM, T7Poultry manure @ 4t/ha + foliar spray of 1\% PPFM, T8- Poultry manure @ 4t/ha + Azophos @ 2kg/ha + foliar spray of $1 \%$ PPFM and T9- Poultry manure @ 4t/ha + Azophosmet @ 2kg/ha + foliar spray of 1\% PPFM was carried with three replications. Foliar spraying of 1\% PPFM was taken up at 45th day after sowing and later at 15 days after first and second harvest i.e., 75 and 105 DAS.

\section{Estimation of total microbial population}

Ten grams of rhizosphere soil sample was transferred to $90 \mathrm{ml}$ of sterile distilled water to get $10^{-1}$ dilution. After thoroughly mixing it, one $\mathrm{ml}$ of this dilution was transferred to 9 $\mathrm{ml}$ water blank to get $10^{-2}$ dilution. Likewise, sample was diluted serially with $9 \mathrm{ml}$ water blanks till appropriate dilution was obtained (Parkinson et al., 1971).

\section{Bacteria (x $10^{6} \mathrm{CFU} \mathrm{g}^{-1}$ soil)}

The total bacterial population was enumerated by plating one $\mathrm{ml}$ of $10^{-6}$ dilution in sterile Petri plates using soil extract agar medium. The bacterial colonies appearing on the plates after $48 \mathrm{~h}$ of incubation at $30 \pm 1{ }^{\circ} \mathrm{C}$ were counted and expressed in colony forming units (CFU) per g dry weight of the soil.

\section{Fungi (x 10 ${ }^{3} \mathrm{CFU} \mathrm{g}^{-1}$ soil)}

For the enumeration of fungal population, one $\mathrm{ml}$ of $10^{-3}$ dilution of the soil sample was plated in sterile plate with Rose Bengal agar medium. After $72 \mathrm{~h}$ of incubation, the fungal colonies were counted and expressed in $\mathrm{CFU}$ per g dry weight of soil.

\section{Actinomycetes (x 10 CFU g $^{-1}$ soil)}

The total actinomycetes population was enumerated by plating $1 \mathrm{ml}$ of $10^{-4}$ dilution with Kenknights agar medium. The powdery colonies of actinomycetes appearing after 5 days were counted and expressed in CFU per g dry weight of soil.

\section{Results and Discussion}

The ultimate goal to be achieved in any crop production programme is maximization of yield. The yield is a complex phenomenon, which can be engineered both by morphological and physiological parameters. The highest herbage yield per hectare was observed in the treatment $\mathrm{T}_{6}$ (Vermicompost 6 tha $^{-1}+$ Azophosmet $2 \mathrm{~kg} \mathrm{ha}^{-1}+$ Foliar spray of $1 \%$ PPFM). The increased yield may be due to synergistic and compatible effect of organic manures and biofertilizers application. The effect of vermicompost on germination, growth and yield of tomato plants were evaluated under glass house conditions by Atiyeh et al., (2000) and Somasundaram et al., (2003) in green gram who found that highest yield attributes were due to the highest mineral nitrogen concentration of vermicompost.

The increase in yield due to the application of vermicompost might be due to the fact that it is originated from organically digested plant materials which have loosely packed granular particles. It is rich in organic matter content and essential nutrients which are present in 
easily available or mineralizable form. Hence, the addition of vermicompost to the soil enhanced the microbial activity of soil and provided more macro and micro nutrients to the plants for better growth. Vermicompost also stimulate the nitrate reductase activity, which regulates the nitrogen availability to the plant. Humic substance present in the vermicompost stimulates the respiration enzyme which could have resulted in increased respiration and increased yield.

Table.1 Effect of organic manures and biofertilizers on fresh herbage yield per plot $\left(\mathrm{kg} \mathrm{plot}^{-1}\right)$ of Black nightshade

\begin{tabular}{|c|c|c|c|}
\hline \multirow{2}{*}{ Treatments } & \multicolumn{3}{|c|}{ Fresh herbage yield per plot $\left(\mathrm{kg} \mathrm{plot}^{-1}\right)$} \\
\cline { 2 - 4 } & 60 DAS & 90 DAS & 120 DAS \\
\hline T1 & 2.14 & 3.27 & 4.23 \\
\hline T2 & 2.23 & 3.39 & 4.11 \\
\hline T3 & 3.91 & 4.35 & 5.12 \\
\hline T5 & 3.07 & 3.21 & 4.25 \\
\hline T6 & 3.17 & 3.43 & 4.27 \\
\hline T7 & 5.99 & 6.97 & 7.91 \\
\hline T8 & 2.03 & 2.29 & 2.38 \\
\hline T9 & 2.81 & 2.92 & 2.82 \\
\hline SEd & 3.03 & 4.02 & 4.27 \\
\hline CD (P=0.05) & $\mathbf{0 . 0 9}$ & $\mathbf{0 . 1 0}$ & $\mathbf{0 . 1 1}$ \\
\hline
\end{tabular}

\section{Treatment details:}

T1- FYM @ 8t/ha + foliar spray of 1\% PPFM

T2-FYM @ 8t/ha+Azophos @ 2kg/ha+ foliar spray of 1\% PPFM

T3- FYM @ 8t/ha+Azophosmet @ 2kg/ha+ foliar spray of 1\% PPFM

T4- Vermicompost @ 6t/ha + foliar spray of 1\% PPFM

T5-Vermicompost @ 6t/ha+Azophos @ 2kg/ha+ foliar spray of 1\% PPFM

T6-Vermicompost @ 6t/ha+Azophosmet@ 2kg/ha+ foliar spray of 1\% PPFM

T7- Poultry manure@ 4t/ha + foliar spray of 1\% PPFM

T8- Poultry manure@ 4t/ha +Azophos @ 2kg/ha+ foliar spray of 1\% PPFM

T9- Poultry manure@ 4t/ha +Azophosmet@ 2kg/ha+ foliar spray of 1\% PPFM 
Table.2 Effect of organic manures and biofertilizers on soil microbial population (Bacteria, Fungi, Actinomycetes) at initial and final stage of Black nightshade crop growth

\begin{tabular}{|c|c|c|c|}
\hline Treatments & $\begin{array}{c}\text { Bacteria } \\
\left(\begin{array}{c}\times 1^{6} \mathrm{CFU} \mathrm{^{-1 }} \\
\text { soil })\end{array}\right.\end{array}$ & $\begin{array}{c}\text { Fungi } \\
\left(\begin{array}{c}\times 10^{3} \mathrm{CFU} \mathrm{g}^{-1} \\
\text { soil })\end{array}\right.\end{array}$ & $\begin{array}{c}\text { Actinomycetes } \\
\left(\begin{array}{c}\text { x } 10^{4} \mathrm{CFU} \mathrm{g}^{-1} \\
\text { soil })\end{array}\right.\end{array}$ \\
\hline $\begin{array}{c}\text { Initial } \\
\text { population }\end{array}$ & 10.2 & 9.3 & 6.02 \\
\hline \multicolumn{4}{|c|}{ Final stage } \\
\hline $\mathbf{T 1}$ & 47.66 & 24.33 & 35.33 \\
\hline $\mathbf{T 2}$ & 88.25 & 27.66 & 45.66 \\
\hline T3 & 91.30 & 42.96 & 81.33 \\
\hline $\mathbf{T 4}$ & 42.66 & 30.33 & 59.70 \\
\hline T5 & 66.50 & 22.33 & 68.64 \\
\hline T6 & 96.76 & 52.46 & 94.66 \\
\hline $\mathbf{T 7}$ & 31.33 & 19.54 & 15.37 \\
\hline T8 & 41.86 & 21.56 & 24.19 \\
\hline T9 & 89.46 & 31.95 & 65.37 \\
\hline SEd & 1.79 & 0.81 & 1.49 \\
\hline $\mathrm{CD}(\mathrm{P}=\mathbf{0 . 0 5})$ & 3.80 & 1.71 & 3.15 \\
\hline
\end{tabular}

\section{Treatment details:}

T1-FYM @ 8t/ha + foliar spray of 1\% PPFM

T2- FYM @ 8t/ha+Azophos @ 2kg/ha+ foliar spray of 1\% PPFM

T3-FYM @ 8t/ha+Azophosmet @ 2kg/ha+ foliar spray of 1\% PPFM

T4-Vermicompost @ 6t/ha + foliar spray of 1\% PPFM

T5-Vermicompost @ 6t/ha+Azophos @ 2kg/ha+ foliar spray of 1\% PPFM

T6-Vermicompost @6t/ha+Azophosmet@ 2kg/ha+ foliar spray of 1\% PPFM

T7- Poultry manure@ 4t/ha + foliar spray of 1\% PPFM

T8- Poultry manure@ 4t/ha +Azophos@2kg/ha+ foliar spray of 1\% PPFM

T9- Poultry manure@ 4t/ha +Azophosmet@ 2kg/ha+ foliar spray of 1\% PPFM 
Fig.1 Best Treatment (T6)

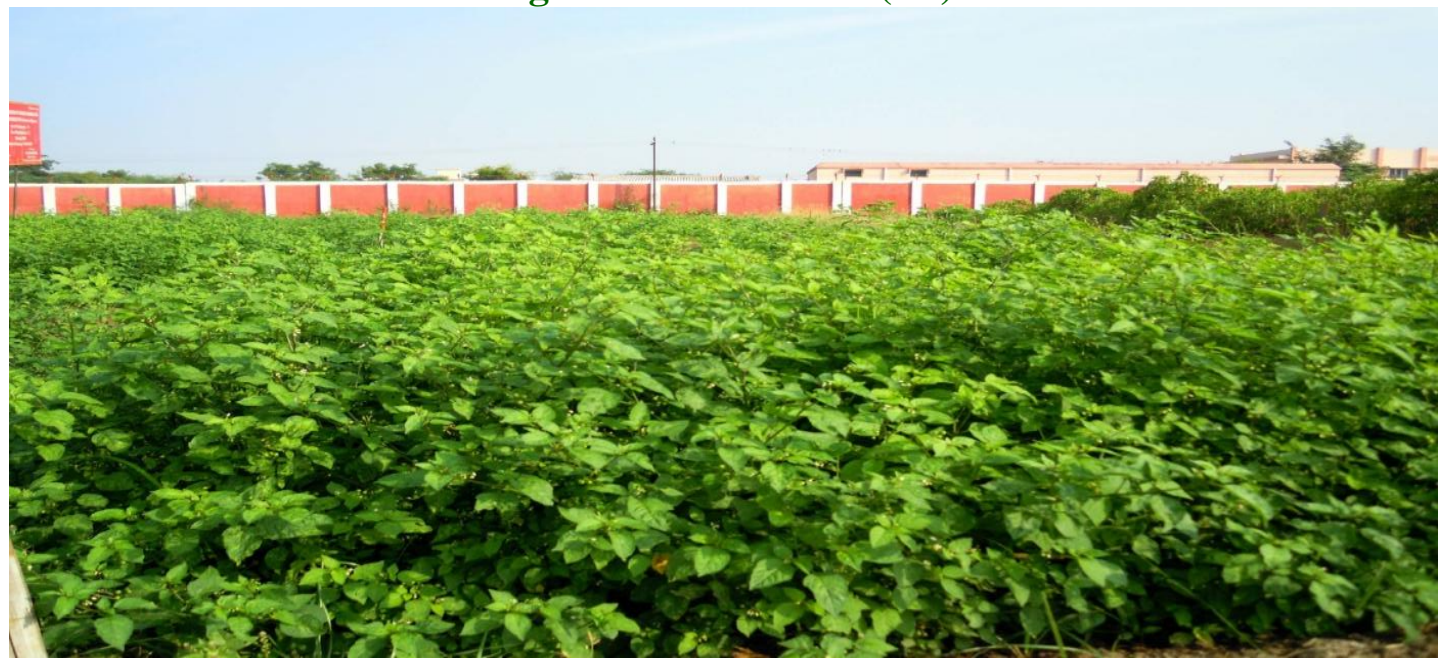

Fig.2

Soil microbial population at initial stage Bacteria

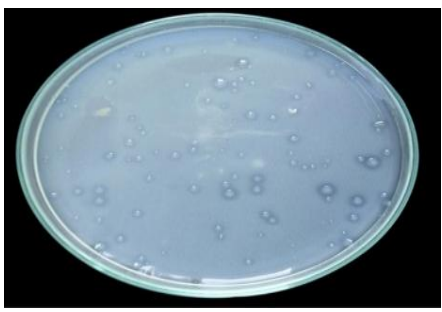

Fungi

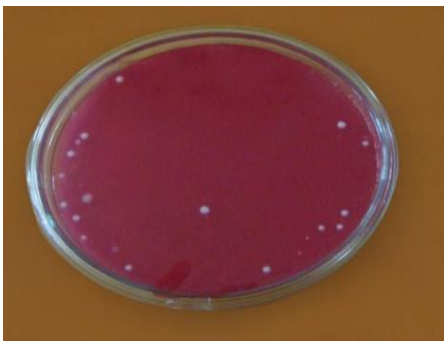

Actinomycetes

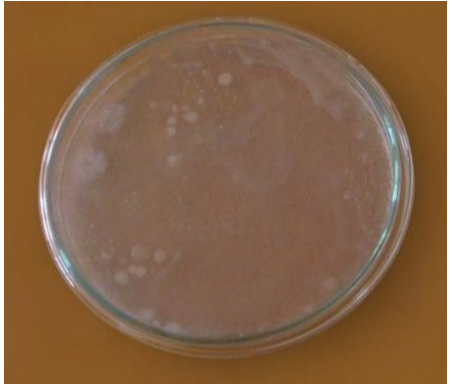

Thus application of vermicompost have stimulated the microorganisms by serving as a
Soil microbial population at final stage Bacteria (T6)

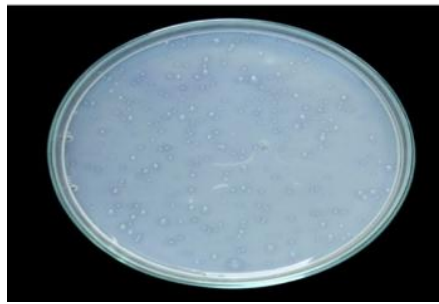

Fungi (T6)

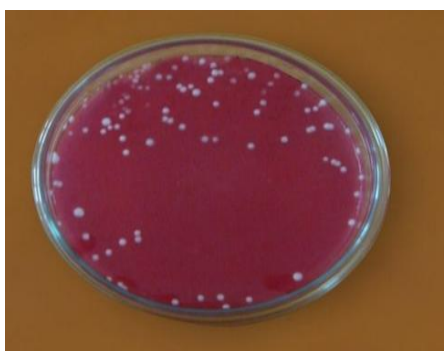

Actinomycetes (T6)

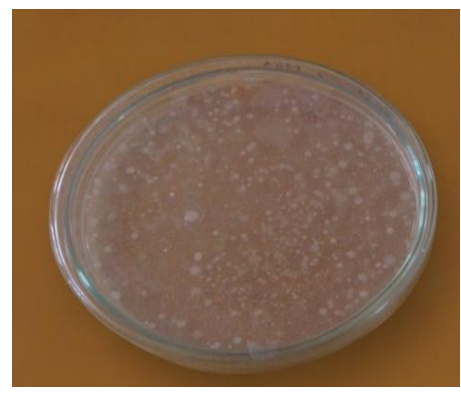

source of $\mathrm{N}$ and other nutrients essential for its growth and multiplication resulting in increased 
yield in Solanum nigrum. Similar report was also stated by Somasundaram et al., (2003) in green gram.

The increased yield ascribed might be due to better soil condition, availability of nutrients, continuous and steady supply of nutrition and greater soil microbial activity thus enhancing the production of phytohormones by the application of organic manures. Presence of bioactive principles like auxin, gibberellin, cytokinin, vitamins and amino acids in biostimulants could have influenced more number of side shoots and yield. The growth promoting activity (and it leads to greater movement and availability of phosphorus and micronutrients to the plant) of PPFM is also a possible reason for higher yield. The results are in corroboration with earlier findings of Thanuja (2002) in black pepper.

In conclusion, in the present study, combined use of organic manures with biofertilizers (Vermicompost $6 \mathrm{t} \mathrm{ha}^{-1}+$ Azophosmet $2 \mathrm{~kg} \mathrm{ha}^{-1}$ + Foliar spray of 1\% PPFM) might have improved the microbial load of the soil, thus increasing the microbial population viz., bacteria, fungi and actinomycetes conspicuously with the application of different organic $\mathrm{N}$ sources. The results obtained in this study are supported by the report of Aira et al., 2002. The attributed reason could be the organic manure addition viz., vermicompost would have resulted in increased secondary and micronutrients in the soil which might have helped to increase the microbial population. Application of vermicompost to the soil could have stimulated actinomycetes and bacteria.

\section{References}

Aira, M., F. Monroy, J. Dominguez, S. Mato. 2002. How earthworm density affects microbial biomass and activity in pig manure. European J. Soil Biol., 38: 7-10.

Atiyeh, R.M., C.A. Edwards, S. Subler and J.D. Metzger. 2000. Pig manure vermicompost as a component of horticultural bedding plant medium: Effect on physicochemical properties and plant growth. Bio Res. Technol., 78(1): 11-20.

Hengeveld, R. 1996. Measuring ecological biodiversity. Biodivers Lett., 3: 58-65.

Luo, Y., Zhou, X. 2006. Soil Respiration and the Environment. Academic Press and Elsevier Inc., Burlington.

Mohamed Saleem, T.S., C. Madhusudhana Chetty, S. Ramkanth, M. Alagusundaram, K. Gnanaprakash, V.S. Thiruvengada Rajan and S. Angalaparameswari. 2010. Solanum nigrum Linn. - A Review Phcog. Rev., 3(6): 342-345.

Parkinson, D., J.R.G. Gray and S.T. Williams. 1971. Methods for studying the Ecology of Soil Microorganisms. Oxford Blackwell Scientific Publications. pp. 116.

Paul, E.A. 2007. Perspective in soil microbiology, ecology and biochemistry. In: Paul E.A. (ed.): Soil Microbiology, Ecology and Biochemistry, Vol. 3. Academic Press and Elsevier Inc., Burlington: 3-24.

Somasundaram, E., N. Sankaran, S. Meena, T.M. Thiyagarajan, K. Chandaragiri and S. Pannerselvam. 2003. Response of green gram to varied levels of panchagavya (organic nutrition) foliar spray. Madras Agric. J., 90: 169-172.

Sundaram, S.P., M. Madhaiyan, M. Senthilkumar, and B.V. Suresh Reddy. 2002. A novel microbial symbiont for using as a bioinoculant. In: Microbial Transformations in Soil (Eds.) Tamil Nadu Agric. Univ., Coimbatore, India, pp.123-131.

Thanuja, T.V. 2002. Arbuscular Mycorrhiza: A low cost technology for pepper nurseries. Spice India, 15(7): 10-14.

\section{How to cite this article:}

Ammaan, M. and Subramanian, S. 2017. Efficacy of Organic Manures and Biofertilizers on Soil Microbial Count and Yield of Black Nightshade (Solanum nigrum L.). Int.J.Curr.Microbiol.App.Sci. 6(7): 1780-1786. doi: https://doi.org/10.20546/ijcmas.2017.607.215 